\title{
MEDIUM DENSITY PARTICLEBOARD USING POSTHARVEST SUGARCANE LEAF STRAW: EFFECT OF RESIN TYPE AND CONTENT, DENSITY AND LAYERS ARRANGEMENT
}

\author{
Divino Eterno Teixeira ${ }^{1 *}$, Keila Lima Sanches ${ }^{2}$, Antonio Carlos Rodrigues de Carvalho ${ }^{3}$ \\ 1* Brazilian Forest Service (SFB), Forest Products Laboratory (LPF). Brasília, DF, Brazil. e-mail: divino.teixeira@ florestal.gov.br \\ 2 Brasília Federal Institute (IFB). Brasília, DF, Brazil. e-mail: keila.sanches@ gmail.com \\ ${ }^{3}$ Brazilian Forest Service (SFB), Forest Products Laboratory (LPF). Brasília, DF, Brazil. e-mail: antonio.carvalho@ florestal.gov.br
}

Received for publication: 26/12/2019 - Accepted for publication: 15/04/2020

\begin{abstract}
Resumo
Painéis de partículas de média densidade (MDP) de palha da folha de cana de açúcar pós-colheita: efeito do conteúdo e tipo de resina, densidade e arranjo das camadas. Formatação: fonte itálico, tamanho 9 sem caixa alta. Chapas de aglomerado de média densidade (MDP), utilizando partículas de palha da folha de cana-deaçúcar (SLS), um subproduto da colheita, coladas com resinas sintéticas (uréia-formaldeído-UF e fenolformaldeído-PF) foram produzidas e avaliadas. As chapas foram avaliadas quanto às propriedades físicas e mecânicas, de acordo com a norma brasileira ABNT NBR 14810-2 (2018). Variáveis de dois tipos de resina, dois teores de resina, dois arranjos de camadas e duas densidades das chapas foram analisados em 12 tratamentos experimentais. Os resultados classificam os painéis como Tipo 2 de acordo com especificações da norma brasileira para uso interno em ambiente seco. Além disso, são viáveis para uso como MDP industrial de acordo com os padrões M1 e M2 das normas ANSI A208.1 (2016). A densidade do painel variou de 0,569 a $0,749 \mathrm{~g} / \mathrm{cm}^{3}$. Geralmente, as propriedades melhoraram com o aumento do conteúdo de resina e densidade dos painéis. Dentre os painéis colados com UF o melhor resultado foi apresentado com camada única, 12\% de sólidos e densidade de $0,75 \mathrm{~g} / \mathrm{cm}^{3}$. Painéis colados com $12 \%$ de PF apresentaram melhores resultados de resistência e melhor estabilidade dimensional. Como um estudo exploratório, os resultados são promissores e é necessário mais trabalho para garantir o uso técnico desse resíduo, que geralmente é queimado e visto como um ônus ambiental.

Palavras-chave: teor de resina; densidade do painel; propriedades físico-mecânicas.
\end{abstract}

\section{Abstract}

Medium Density Particleboard (MDP) using sugarcane leaf straw (SLS) particles, a byproduct of the sugarcane harvesting, bonded with synthetic resins (urea-formaldehyde-UF and phenol-formaldehyde-PF) was produced and evaluated. Panels were tested for physical and mechanical properties, according to Brazilian standard ABNT NBR 14810-2 (2018). Variables of two types of resin, two resin contents, two arrangements of board layers and two board densities were analyzed in 12 treatments experimental design. The results grade the panels as Type 2, according to specifications of the Brazilian standard, for internal/dry use. They are also graded as classes M1 and M2 of the ANSI A208.1 (2016) standards for use as industrial MDP. Board density varied from 0.569 to $0.749 \mathrm{~g} / \mathrm{cm}^{3}$. Generally, properties improved with the increase of resin content and density. Among the panels bonded with UF the best result was presented with single layer, $12 \%$ solids and density of $0.75 \mathrm{~g} / \mathrm{cm}^{3}$. Panels glued with $12 \%$ PF showed best results of resistance and improved dimensional stability. As an exploratory study, the results are promising and further work is needed to assure the technical use of this agricultural waste, which is usually burned and seen as an environmental burden.

Keywords: resin content; board density; physical and mechanical properties.

\section{INTRODUCTION}

The industry of reconstituted wood-based panels has contributed significantly to the Brazilian economy generating a great supply of products for various applications, as well as providing more jobs.

According to data from the Brazilian Tree Industry (IBÁ, 2019), 8.16 million $\mathrm{m}^{3}$ of reconstituted wood panels were produced in 2018, from which, $40 \%$ of MDP, 56\% of MDF and 4\% hardboard (HDF). As defined by the ABNT NBR 14810-1 (2013), Medium Density Particleboard (MDP) is a reconstituted particle panel bonded with synthetic resins with density ranging from $551 \mathrm{~kg} / \mathrm{m}^{3}$ to $750 \mathrm{~kg} / \mathrm{m}^{3}$.

From the economic data, we can observe the importance of this industrial sector in the nation's economy. Therefore, studies related to the production of MDP, using residues, either from industrial or agricultural fibers, are an important alternative to cellulosic fiber raw material. Alternatively, a large amount of agricultural waste is generated in the production mills. Residues such as corn husk and sugar cane bagasse, dry leaves and green tops constitute a source of raw material that can be used in part to produce energy and to feed livestock (MENANDRO et al., 2017; CHANDEL et al., 2011; CARVALHO et al., 2016). 
The sugarcane production in Brazil in 2018/2019 was 620 million tons, 53.6\% just in the state of São Paulo. The planted area was almost 9 million hectares (CONAB, 2019). From this total, about 70\% was harvested by burning the dry leaves and only $30 \%$ without the use of fire. The practice of fire use has constituted a major environmental and health problem for the population and a liability for the industries. Decree $\mathrm{n}^{\circ}$. 47700, dated March 11, 2003, regulating Law $\mathrm{n}^{\circ}$. 11241, of September 19, 2002, establishes that the practice of burning sugarcane leaves will be gradually terminated by 2031 (CONAB, 2019). Out of a ton of sugarcane produced, about $14 \%$ is leaf. Even though part of it is incorporated into the soil, a large amount is still left unused.

Wheat straw and sugarcane bagasse are agricultural residues used industrially in other countries as raw material for the production of reconstituted wood panels. Particleboard of various densities with $100 \%$ of this material are produced by Sorm Inc. Sorm Inc. (2019a) produced particleboard utilizing sunflower and wheat straw as well, bonded with isocyanate-based resin (MDI), more moisture-resistant and formaldehyde-free. Low density panels, called ultra-low-density (ULD) and low-density (LD), in the range of 280 to $350 \mathrm{~kg} / \mathrm{m}^{3}$ and 415 to 450 $\mathrm{kg} / \mathrm{m}^{3}$, respectively, are used for insulation as doors core. MDP (608 to $720 \mathrm{~kg} / \mathrm{m}^{3}$ ) is used to produce furniture, cabinets, partitions, offices, schools, offices, etc. They are rated as grades M1 to M3 by the American standard ANSI A208.1 (2016) and are machined and coated in the same way as wood-based panels.

Santana and Teixeira (1996) developed a MDP using sugarcane bagasse, which received a patent certificate, with properties similar to those of commercial wood particles according to Brazilian standards. Other studies are available on the use of agricultural residues such as wheat straw for particleboard production (BEKHTA et al., 2013; ZHANG et al., 2011; ZHU, 2012)

On the other hand, there is a need to find new sources of plant fibers as alternative raw material for the production of reconstituted panels. Other industrial segments, such as cellulose, flooring, energy and solid wood, are increasingly demanding forest resources in Brazil.

This project aims to analyze the quality of MDP composed of agricultural residue of sugarcane leaf straw particles and adhesives (urea-formaldehyde and phenol-formaldehyde), in order to verify the technical feasibility of a new technology in the productive market of particleboards.

\section{MATERIALS AND METHODS}

\section{Obtaining the particles of residues from sugarcane leaves straw (SLS).}

The SLS was obtained from an ethanol production mill in the countryside of São Paulo state, fragmented in an agricultural grinder, collected and selected in fines and coarse, using screen sieves of $3.0 \mathrm{~mm}, 1.5 \mathrm{~mm}$ and $1.0 \mathrm{~mm}$ openings, in the desired granulometry for the manufacture of panels at the Forest Products LaboratoryLPF in Brasilia, Brazil. Particles processed in the screen sieves were classified and separated into another classifier in fines passing the screen of 35 mesh and collected in the bottom.

The selected and classified material was submitted to pre-drying to reduce the initial moisture content and used on the MDP panels manufacturing.

A sample of $1.0 \mathrm{~g}$ of particles was collected and milled to determine the ash content according to ASTM E1755-01 (2015) standard.

The methodology is represented in the flow chart of Figure 1.

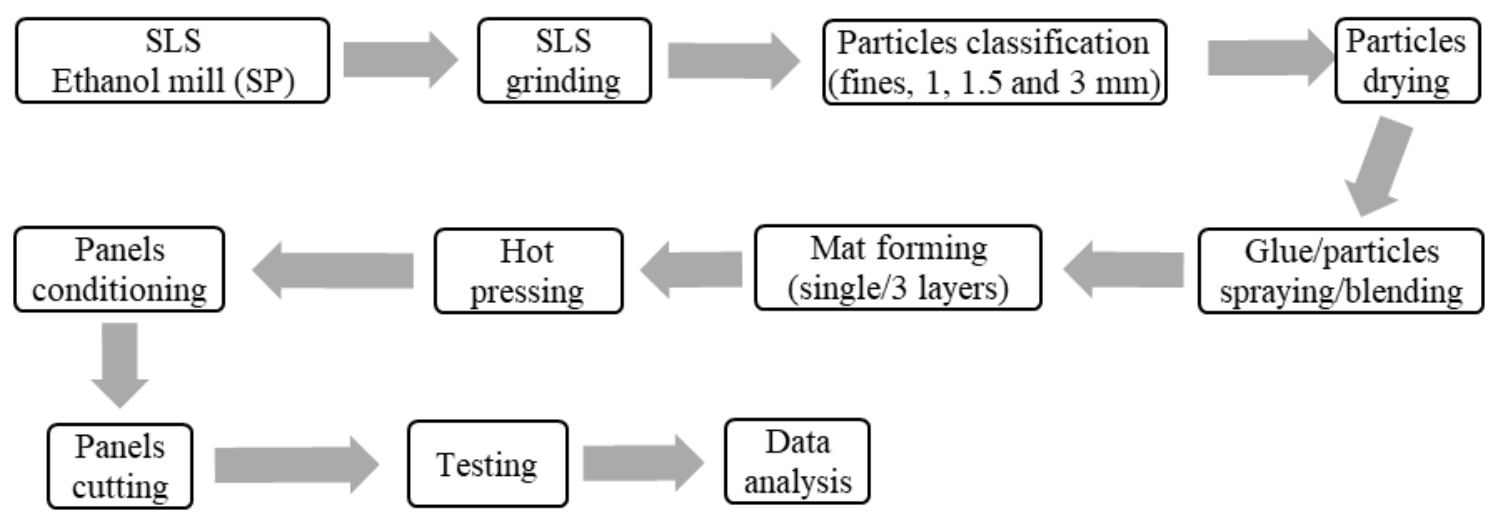

Figure 1. Flow chart of the methodology (SLS = sugarcane leaves straw).

Figura 1. Fluxograma de realização do experimento (SLS = palha da folha de cana-de-açúcar). 


\section{Adhesive preparation}

Two types of adhesives were selected for the manufacture of sugarcane leaves straw MDP: ureaformaldehyde (UF) and phenol-formaldehyde (PF).

The commercial name of the urea-formaldehyde adhesive is Cascamite PB 5010, supplied by Hexion Química. The viscosity of the adhesives was estimated and adjusted using a Brookfield viscometer, model RVF 100 , to $400 \mathrm{mPa} . \mathrm{s}$ and $2 \%$ (relative to the adhesive) of K6 catalyst was mixed to the resin. The solids content of $65 \%$ and $\mathrm{pH}$ of 8.2 .

The commercial name of the phenol-formaldehyde adhesive is Cascophen HL-2080, also provided by Hexion Química. The solids content of 49\%, pH of 12, and the viscosity was adjusted to $500 \mathrm{mPa}$.s and no catalyst was added to either resin.

\section{Manufacture of the MDP}

The procedures for making the sugarcane leaf straw MDP were as follows:

The adhesive was prepared by adjusting the viscosity to $400 \mathrm{mPa}$.s. The sugarcane straw particles were dried to $4 \%$ to $5 \%$ moisture content.

An amount of straw (coarse particle) was mixed with enough adhesive for three replicates (panels) using a DRAIS glue mixer. Single-layer and three-layer panels were manufactured. Single-layer panels were produced mixing particle sizes of 1.5 plus $1.0 \mathrm{~mm}$ and only for the $12 \%$ resin content treatments. For the $8 \%$ resin content treatments, three-layer panels were composed of course particles in the core and fines in the faces in proportions of $15 \% / 85 \%$ (face/core) to form mats of $30 \times 30 \mathrm{~cm}$.

After assembling, the mats were loaded on the hot press with $10 \mathrm{~mm}$-thick stopping bars. The pressing was adjusted so that the temperature was between 170 and $195^{\circ} \mathrm{C}$, according to the resin manufacturer instructions. The pressure was adjusted to reach the stop bars and density for each treatment.

After conditioning, the panels were cut into specimens of 250x50 mm for the measurement of the apparent density (at $12 \%$ moisture content) and for the static bending tests and $50 \times 50 \mathrm{~mm}$ for the thickness swelling and water absorption tests. The static bending test was performed with a span of $200 \mathrm{~mm}$ between supports and a load cell of 2,000 kgf. The dimensions of the specimens and the test procedure followed the ABNT NBR 14810-2 (2018) standards for MDP.

Variables including resin type (two), layers arrangement (two), panel apparent density (two) and resin percentage (two) were evaluated in a treatment arrangement as shown in Table 1.

Table 1. Experimental design.

Tabela 1. Delineamento experimental.

\begin{tabular}{cccccc}
\hline Treatment $^{1}$ & $\begin{array}{c}\text { Target Density }^{\mathbf{2}} \\
\left(\mathbf{g} / \mathbf{c m}^{\mathbf{3}}\right)\end{array}$ & Resin type $^{\mathbf{3}}$ & $\begin{array}{c}\text { Resin } \\
\text { content }\end{array}$ & $\begin{array}{c}\text { Particle granulometry } \\
\text { (screen opening) }^{\mathbf{2}}\end{array}$ & $\begin{array}{c}\text { Number of } \\
\text { layers }\end{array}$ \\
\hline A & 0.65 & UF & $8 \%$ & $3 \mathrm{~mm}+$ fines & 3 \\
B & 0.75 & UF & $8 \%$ & $3 \mathrm{~mm}+$ fines & 3 \\
C & 0.65 & UF & $8 \%$ & $1.5 \mathrm{~mm}+$ fines & 3 \\
D & 0.75 & UF & $8 \%$ & $1.5 \mathrm{~mm}+$ fines & 3 \\
E & 0.65 & PF & $8 \%$ & $3 \mathrm{~mm}+$ fines & 3 \\
F & 0.75 & PF & $8 \%$ & $3 \mathrm{~mm}+$ fines & 3 \\
G & 0.65 & PF & $8 \%$ & $1.5 \mathrm{~mm}+$ fines & 3 \\
H & 0.75 & PF & $8 \%$ & $1.5 \mathrm{~mm}+$ fines & 3 \\
I & 0.65 & UF & $12 \%$ & $1.5+1.0 \mathrm{~mm}$ & 1 \\
J & 0.75 & UF & $12 \%$ & $1.5+1.0 \mathrm{~mm}$ & 1 \\
K & 0.65 & PF & $12 \%$ & $1.5+1.0 \mathrm{~mm}$ & 1 \\
L & 0.75 & PF & $12 \%$ & $1.5+1.0 \mathrm{~mm}$ & 1
\end{tabular}

(1) Three panels/treatment (36 total); $\left({ }^{2}\right)$ apparent density (at 12\% moisture content); $\left({ }^{3}\right)$ UF $=$ urea formaldehyde; PF = phenol-formaldehyde; $\left.{ }^{4}\right)$ Three layer boards: fines in the surfaces. Single layer: $1.5+1.0 \mathrm{~mm}$ mixing the two straw granulometries. 


\section{Analysis of the data obtained}

The data obtained in the tests were organized and submitted to statistical analysis using the SPSS Plus statistical software. The means were separated by the Tukey HSD test at $5 \%$ significance level. The experimental unit was each specimen.

\section{RESULTS}

\section{Features of the SLS particles}

The analysis of the SLS particles are presented in Table 2.

Table 2. Analysis of the ash proportions in the SLS and tauari wood as a comparison.

Tabela 2. Proporções de cinza nas partes da palha da folha de cana-de-açúcar e de madeira de tauari como comparação.

\begin{tabular}{lcccc}
\hline Proportion & $\begin{array}{c}\text { Central } \\
\text { nervure }\end{array}$ & Foliar laminae & Integral & Tauari \\
\hline Ash content (\%) & 4.54 & 10.0 & 10.06 & 0.55 \\
$\%$ Foliar/nervure & 49.0 & 51.0 & - & - \\
\hline
\end{tabular}

Bulk density of the SLS $=91 \mathrm{~kg} / \mathrm{m}^{3}$.

The analysis of the sugarcane straw showed high ash content in the leaf area (10\%) compared to $0.55 \%$ in the sawdust from tauari wood (Couratari sp.). The leaf area provides resistance to the panels due to the fibers content, while the central nervure is composed by parenchyma. The amount of leaf area $(51 \%)$ is almost the same of nervure (49\%). $\mathrm{kg} / \mathrm{m}^{3}$.

The bulk specific mass of the straw at $4 \%$ moisture was $91 \mathrm{~kg} / \mathrm{m}^{3}$, while the tauari wood mass was 450

The yields of sugarcane straw after the classification in several screen sieve amounted to $24.93 \mathrm{~kg}$. The material retained in the $5.0 \mathrm{~mm}$ opening screen (8.3\%) was reprocessed in the grinder and classified. It is observed that the largest proportion of material, $42.7 \%$, is powder (fines), retained in the $1.0 \mathrm{~mm}$ mesh sieve and at bottom that passed through this sieve. Particle sizes of $1.0 \mathrm{~mm}, 1.5 \mathrm{~mm}$ and $3.0 \mathrm{~mm}$ were $29.5 \%, 7.9 \%$ and $11.7 \%$, respectively.

The slenderness ratio of each type of particle was measured, taking the relation of length/thickness of 100 particles of each type. For the $1.5 \mathrm{~mm}$ sieve particle the ratio was 163.2, with an average length of $10.7 \mathrm{~mm}$ and a thickness of $0.15 \mathrm{~mm}$. For the $3.0 \mathrm{~mm}$, the ratio was 150.2, with an average length of $11.19 \mathrm{~mm}$ and a thickness of $0.26 \mathrm{~mm}$.

The standard slenderness ratio for three-layer panels may range from 120 to 200 for outer layer particles and 60 for inner panel layer particles (IWAKIRI, 2005). Iwakiri (2005) indicates that for panels of homogeneous layers, the static flexural strength increases linearly with the slenderness ratio up to 120 , remaining stable above this value.

Brito and Peixoto (2000) describe that the slenderness ratio of particles has a direct relationship with the Modulus of Elasticity (MOE) and this value must be at least 200. Therefore, the slenderness of the straw particles is within the acceptable.

\section{MDP properties}

The moisture content of the panels ranged from $7.3 \%$ to $10.0 \%$, with an average of $8.4 \%$. These values meet the ABNT Standard for Medium Density Particleboard (NBR 14810-2, 2018), which establishes a limit range of $5 \%$ up to $11 \%$.

Figures 2 to 6 present the average results of the physical and mechanical properties and the statistical analysis of the Tukey test at 5\% significance level.

Figure 2 shows the results and comparison of the target density and the density of the manufactured MDP. The apparent density of the panels ranged from 0.569 to $0.749 \mathrm{~g} / \mathrm{cm}^{3}$, exactly within the range of MDP panels according to ABNT NBR 14810-1 (2013). The coefficient of variation within each treatment was in the range of $2.4 \%-6 \%$, indicating good homogeneity in the manufacture of the panels. 


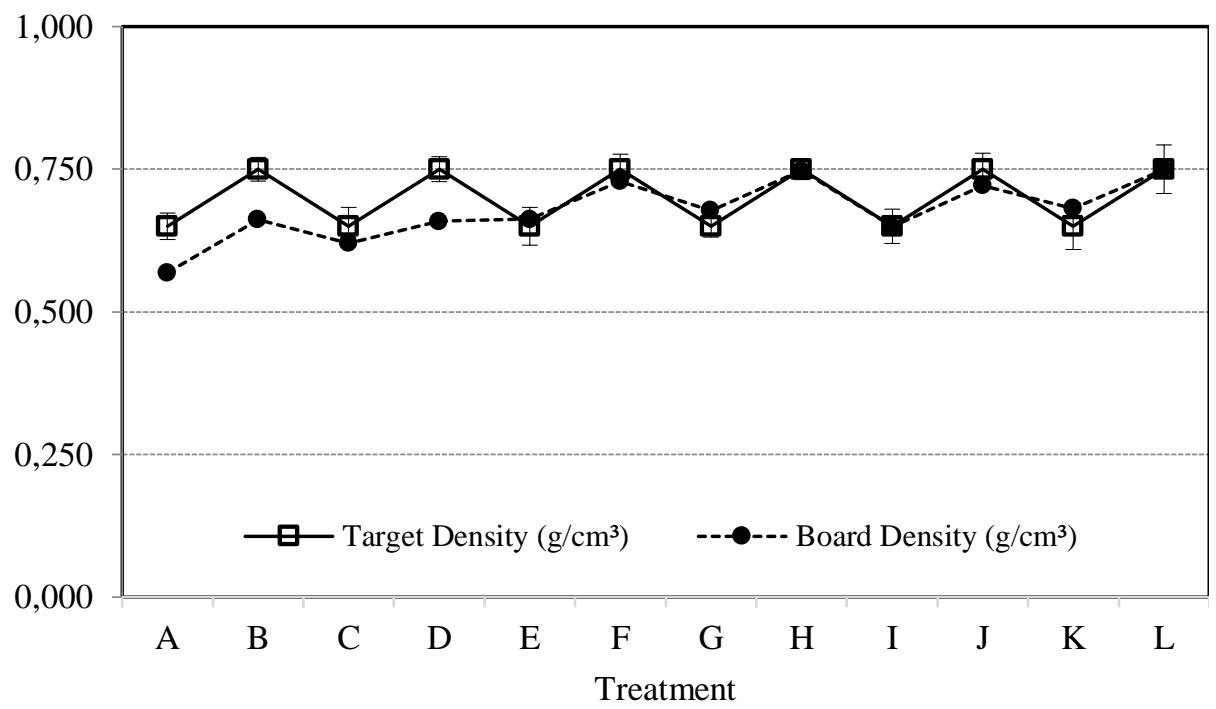

Figure 2. Target apparent (12\% moisture content) density and density of the sugarcane leaf straw MDP ("I" lines are MDP standard deviation).

Requirements: ANSI A2081 (0.640/0.800); Prairie² (0.720); ABNT 14810-23 (0.559-0.750).

(1) Industrial particleboard grades M1 and M2;

(2) Industrial particleboard of wheat straw marketed for internal use;

(3) Grade P2 nonstructural dry internal use MDP.

Figura 2. Densidades aparentes (12\% umidade) nominais e do MDP de palha de folhas de cana-de-açúcar (linhas "I" são desvio padrão do MDP).

Requisitos: ANSI A208¹ (0,640/0,800); Prairie $^{2}(0,720)$; ABNT 14810-23 (0,551-0,750).
(1) Classes M1 e M2 para aglomerado industrial;
(2) Valores de aglomerado industrial de palha de trigo comercializado para uso interno;
(3) Classe P2 de aglomerado não estrutural de uso interno em condição seca.

The results of the thickness swelling and water absorption properties are shown in Figures 3 and 4 .

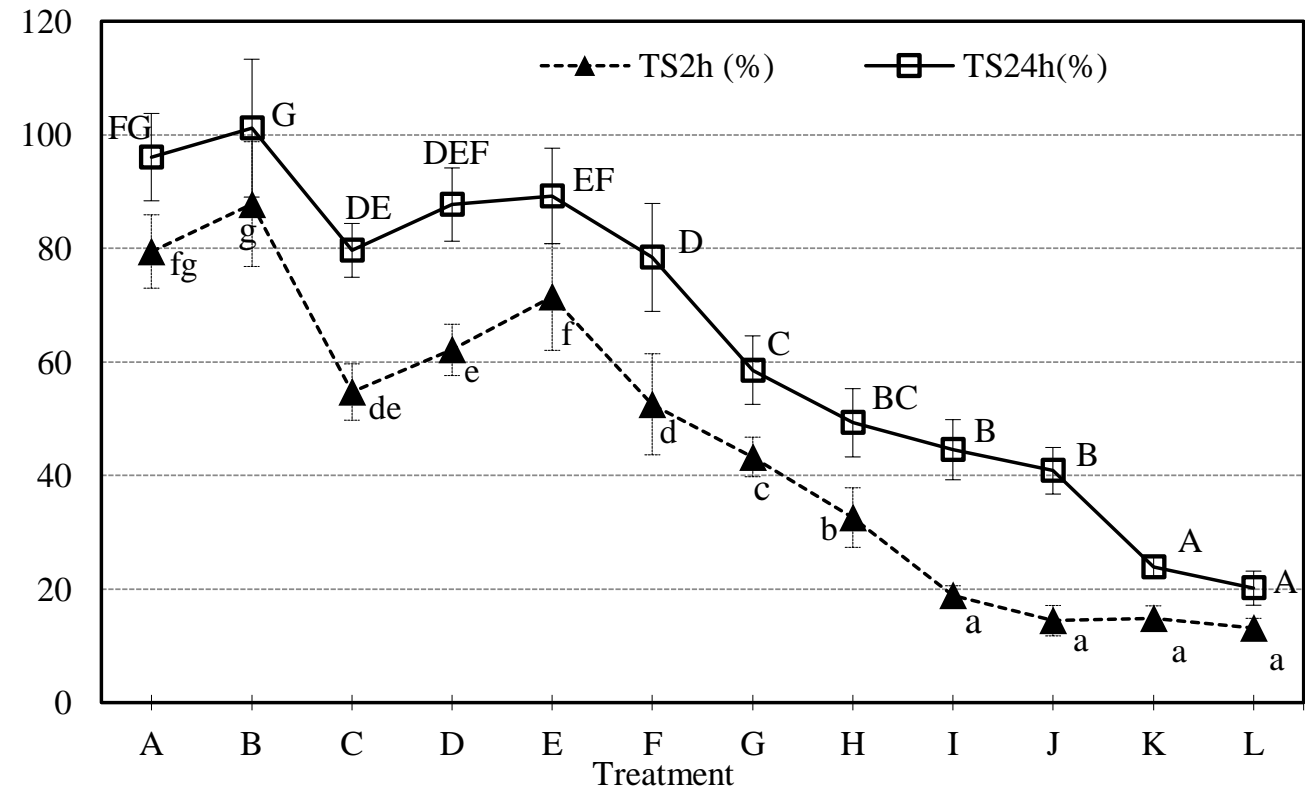

Figure 3. Thickness Swelling (TS) of the sugarcane leaf straw MDP after 2- and 24-hours water immersion ("I" lines are standard deviation; lower/capital letters for each property means statistical differences on the Tukey test at 5\% significance level).

Requirements: Prairie ${ }^{2}$ (20\%-25\%); ABNT 14810-23 (22\%)

(1) Values after $24 \mathrm{~h}$ of an industrial particleboard of wheat straw marketed for internal use;

(2) Value after $24 \mathrm{~h}$ for P2 nonstructural dry internal use MDP. 
Figura 3. Inchamento em espessura (TS) de MDP de palha de folhas de cana açúcar após 2 e 24 horas de imersão em água (linhas "I" são desvio padrão; letras minúsculas/maiúsculas significam diferenças significativas em cada propriedade pelo teste de Tukey ao nível de 5\% de significância).

Requisitos: Prairie ${ }^{1}(20 \%-25 \%)$; ABNT 14810-2² (22\%).

(1) Valores máximos após 24h de aglomerado industrial de palha de trigo comercializado para uso interno;

(2) Valor máximo após 24h para classe P2 de aglomerado não estrutural de uso interno em condição seca.

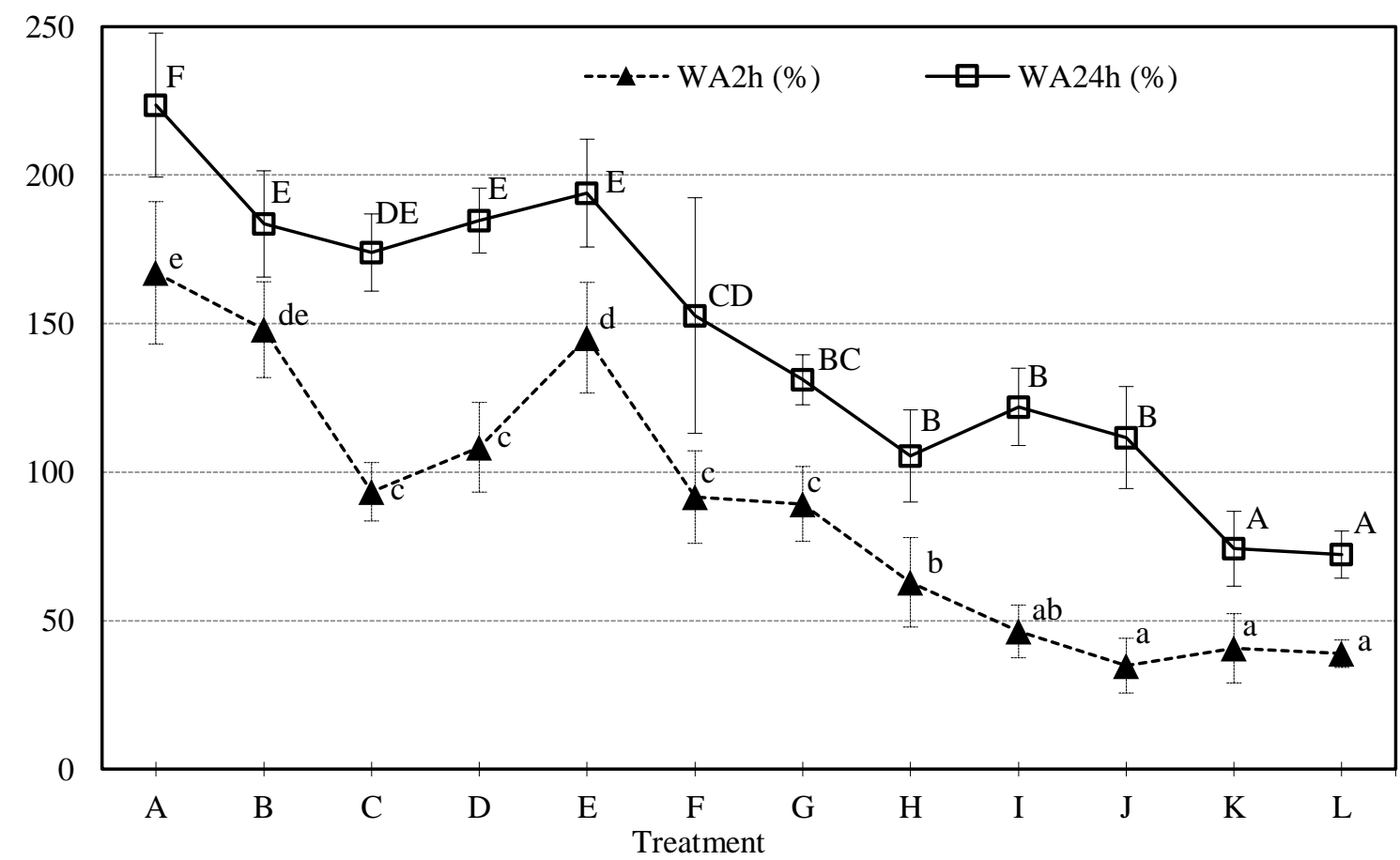

Figure 4. Water Absorption (WA) of the sugarcane leaf straw MDP after 2- and 24-hours water immersion ("I" lines are standard deviation; lower/capital letters for each property means statistical differences on the Tukey test at $5 \%$ significance level).

Figura 4. Absorção de água (WA) de MDP de palha de folhas de cana-de-açúcar após 2 e 24 horas de imersão em água (linhas "I" são desvio padrão; letras minúsculas/maiúsculas significam diferenças significativas em cada propriedade pelo teste de Tukey ao nível de 5\% de significância).

The values obtained for the dimensional stability of thickness swelling (TS) test after 2-hour immersion ranged from $13.1 \%$ to $87.8 \%$ and after $24 \mathrm{~h}$ from $20.2 \%$ to $101.2 \%$, treatments I, J, K and L being the lower and B the higher values, respectively. The coefficient of variation ranged from 5.9\% to $14.9 \%$ for TS24h.

Regarding water absorption (WA), after 2-hour immersion values ranged from $34.8 \%$ (Treatment $\mathrm{J}$ ) to $167.1 \%$ (Treatment A) and after $24 \mathrm{~h}$ from $72.2 \%$ (Treatment L) to $223.6 \%$ (Treatment A). The coefficient of variation ranged from $5.9 \%$ to $26 \%$ for WA24h.

The Modulus of Rupture (MOR) ranged from 4.8 to $14.3 \mathrm{MPa}$ and Stress at Proportional Limit (SPL) ranged from 4.1 to $12.2 \mathrm{MPa}$ (Figure 5). The SPL follows the same tendency of MOR. While MOR is a property of the panel for ultimate strength, SPL is a property used for the safe structural application of the material. The coefficient of variation ranged from $9 \%$ to $27.9 \%$ and from $11 \%$ to $36.6 \%$ for MOR and SPL, respectively. 


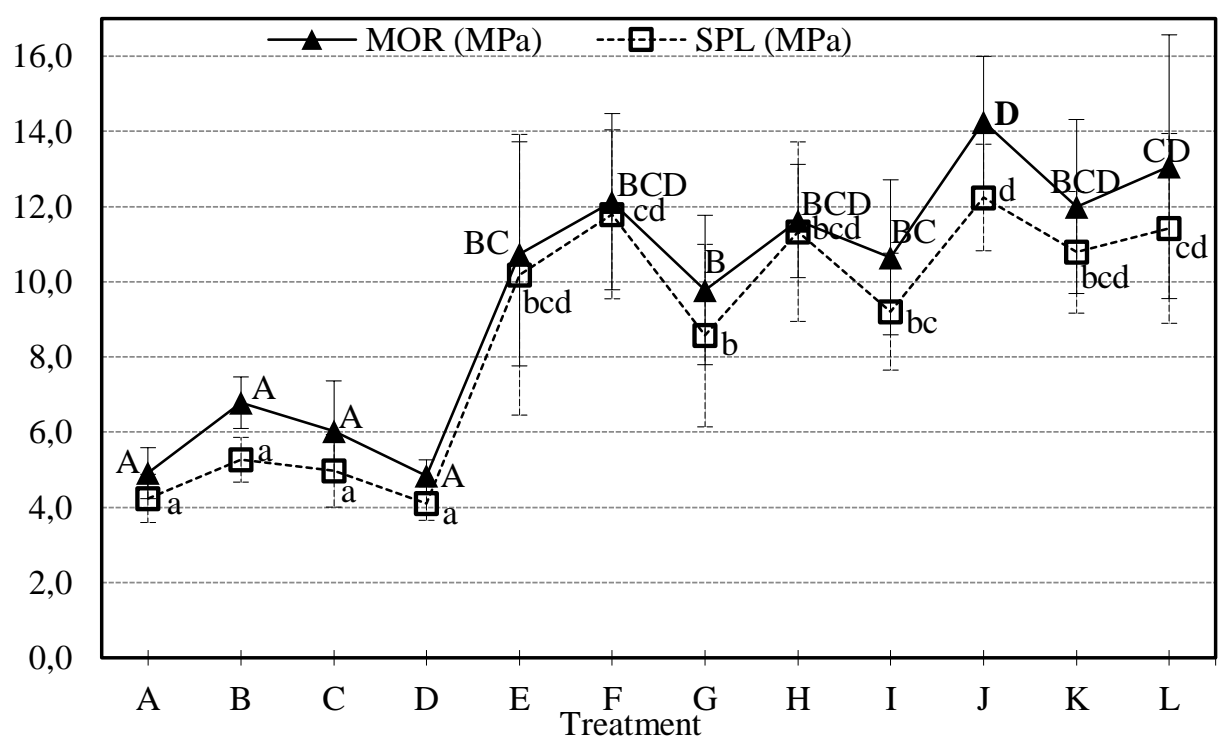

Figure 5. Modulus of Rupture (MOR) and Stress at Proportional Limit (SPL) of the sugarcane leaf straw MDP ("I" lines are standard deviation; lower/capital letters for each property means statistical differences on the Tukey test at 5\% significance level).

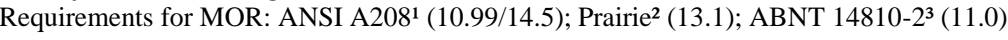

(1) Industrial particleboard grades M1 and M2;

(2) Industrial particleboard of wheat straw marketed for internal use;

(3) Grade P2 nonstructural dry internal use MDP.

Figura 5. Módulo de Ruptura (MOR) e Tensão no Limite Proporcional (SPL) de MDP de palha de folhas de canade-açúcar (as linhas "I" são desvio padrão; letras minúsculas/maiúsculas significam diferenças significativas em cada propriedade pelo teste de Tukey ao nível de $5 \%$ de significância).

Requisitos para MOR: ANSI A2081 (10,99/14,5); Prairie² $^{(13,1) \text {; ABNT 14810-2 }}(11,0)$

(1) Classes M1 e M2 para aglomerado industrial;

(2) Aglomerado industrial de palha de trigo comercializado para uso interno;

(3) Classe P2 de aglomerado não estrutural de uso interno em condição seca.

As shown in Figure 6, the MOE varied from 696 to 1,999 MPa, with coefficient of variation in the range of $8.8 \%-25.8 \%$.

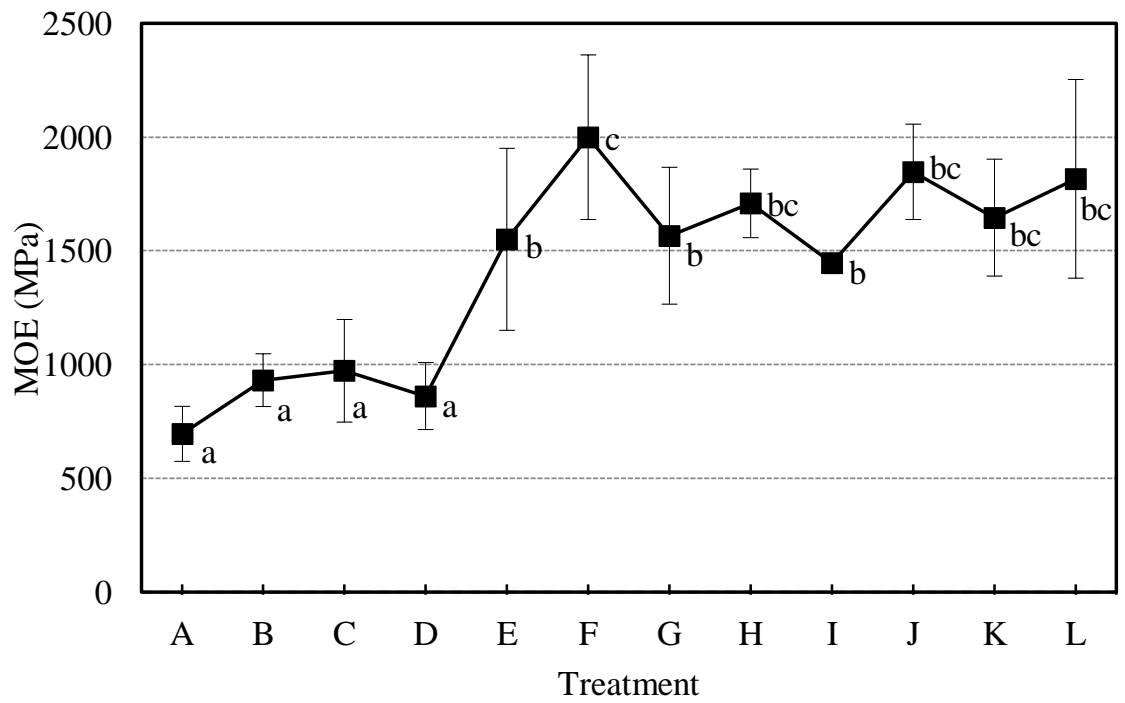

Figure 6. Modulus of Elasticity (MOE) of the sugarcane leaf straw MDP ("I" lines are standard deviation; lower/capital letters for each property means statistical differences on the Tukey test at $5 \%$ significance level).

Requirements: ANSI A2081 (1,725/2,253); Prairie $^{2}$ (2,413); ABNT 14810-2³ (1,800)

(1) Industrial particleboard grades M1 and M2; 
(2) Industrial particleboard of wheat straw marketed for internal use;

(3) Grade P2 nonstructural dry internal use MDP.

Figura 6. Módulo de elasticidade (MOE) de MDP de palha de folhas de cana (linhas "I" são desvio padrão; letras minúsculas/maiúsculas significam diferenças significativas em cada propriedade pelo teste de Tukey ao nível de $5 \%$ de significância).

Requisitos: ANSI A208¹ (1.725/2.253); Prairie² (2.413); ABNT 14810-23 (1.800).

(1) Classes M1 e M2 para aglomerado industrial;

(2) Aglomerado industrial de palha de trigo comercializado para uso interno;

(3) Classe P2 de aglomerado não estrutural de uso interno em condição seca.

\section{DISCUSSION}

\section{Physical properties}

The apparent density of the panels were close to the target density, as shown in Figure 2. Only treatments A, B and D deviated from the target density. It happened in the beginning of the boards' manufacture, due to the novelty of using a different fiber source such as SLS and loss of material.

The addition of a higher proportion of resin (12\%) to the mixture, regardless of board density, contributed to the higher dimensional stability results of thickness swelling after 2 hours of water immersion. After 24 hours of immersion, only the panels bonded with PF resin presented the higher dimensional stability, same observed for the water absorption after the two immersion periods. Regarding the UF based resin, it is less resistant to moisture at a longer period of exposure.

Analyzing only the type of resin, the ANOVA $(p<0.05)$ showed that panels glued with PF are more dimensionally stable. Regarding the type of straw granulometry and number of layers of the panels, the test $(p<0.05)$ showed that the single layer is more resistant than the three-layer, regardless the size of the particles, both for swelling and water absorption.

The increase in board density causes an increase in thickness swelling when UF resin is used at the $8 \%$ level. In this case, there is an increase in the compaction rate of the panels, which produces greater internal stress that is released in part in the water immersion. For panels bonded with PF the opposite takes place. It is emphasized that the first type of resin does not have resistance to moisture, as does the second.

At $12 \%$ resin level, regardless of type, there was a decrease of water intake, resulting in higher stabilization. Here particle adhesion compensates for the release of internal stresses and increases board stability.

The tendency is very similar to the water absorption.

In general, the treatments $\mathrm{K}$ and $\mathrm{L}$ presented the higher dimensional stability after $24 \mathrm{~h}$ immersion, equaling values of the particleboard of wheat straw marketed for internal use by Sorm Inc. (SORM INC., 2019a; SORM INC., 2019b; SORM INC., 2019c).

In addition, panels of treatments $\mathrm{K}$ and $\mathrm{L}$ were similar in terms of WA24h (from $50.83 \%$ to $70.05 \%$ ) and TS24h (from $18.64 \%$ to $26.26 \%$ ) to those manufactures by Iwakiri et al. (2019).

It should be mentioned that no chemical additive commonly used in industry, such as paraffin, was added to improve the dimensional stability of the panels.

\section{Mechanical properties}

The statistical analysis showed that treatments A, B, C, and D, glued with $8 \%$ UF resin, presented lower values of MOR. However, MOR of panels bonded with PF resin, either at $8 \%$ or $12 \%$ solids content, showed substantial improvement. The treatments F, H, J, K and L, mostly PF bonded, met specifications of the ABNT standard (NBR 14810-2, 2018) of 11.0 MPa for P2 graded MDP. Several treatments presented MOR equal to or higher than the requirements of the American standard ANSI A208.1 (2016) for the industrial particleboard grades M1 and M2, which are respectively 10.99 and 14.5 MPa.

The panels of treatments F, J, K and L bonded with $12 \%$ resin were similar in terms of bending strength compared to MDP of Pinus sp. with $8 \%$ of UF resin and $1 \%$ of paraffin emulsion reported by Iwakiri et al. (2019) (MOR from 7.88 to $12.31 \mathrm{MPa}$; MOE from 1,993 MPa to 1,648 MPa).

Dettmer and Smith (2015) conducted a study to identify and compare the mechanical and physical properties of U.S. and Canadian industrial manufactured particleboards. The goal of the survey was to identify panel characteristics, furnish compositions (including species and particle/fiber sizes), resin delivery systems, and the mechanical properties of the boards. The results were similar to the obtained in the current study.

The treatment $\mathrm{F}$ ( $8 \%$ of PF in 3 layers) was the largest absolute MOE (1,999 MPa). Treatments F, J and L met specifications of the ABNT standard (NBR 14810-2, 2018) of 1,800 MPa for P2 graded MDP. Some values were close to or greater than the requirements of grade M1 of ANSI A208.1 (2016) standards.

In general, treatments $\mathrm{J}$ and $\mathrm{L}$ showed resistance equal to or greater than the values of wheat straw particleboard grades M1 and M2 of ANSI A208.1 (2016) for use in furniture in the USA (SORM INC., 2019b;

FLORESTA, Curitiba, PR, v. 51, n. 3, p. 576-585, jul/set 2021

Teixeira, D. E. et.al. 
SORM INC., 2019c; SORM INC., 2019d). This brand of particleboard marketed as Primeboard for internal use by Sorm Inc. since 1995, uses isocyanate resin (MDI) in its production and receives finishing of resins, coatings, Formica, etc. (ANDERSON et al., 2008).

The analysis taking into account only the type of glue $(p<0.05)$ showed that the phenolic resin $(\mathrm{PF})$ presented higher resistance. As for the type of straw and number of panel layers, the Tukey test $(p<0.05)$ showed that the single layer is more resistant than the three-layer arrangement, regardless of the particle size. The same was observed for panels with the highest proportion of resin. Taking into account only the nominal density, MDP with higher density is more resistant, even though with little difference.

\section{CONCLUSIONS}

- Medium Density Particleboard produced with sugarcane straw particles presented good technical characteristics as for the exploratory study and can be graded as P2 (nonstructural internal for use in dry areas) according to requirements of Brazilian technical standard of MDP panels. Some treatments showed properties equal to or greater than the requirements of the American standard ANSI A208.1 (2016) for industrial particleboard. Due to this exploratory nature, the characteristics obtained can still be improved as they are studied, thus eliminating some expendable variables in order to obtain the best final product.

- In general, UF and PF resins applied in proportions close to that used by the wood panel industry can be used in order to obtain a product that meets the Brazilian standard for MDP, however a proportion equal or higher than $12 \%$ of resin content must be used in the mixture.

- Overall, the best result was obtained for panels bonded with PF resin, without addition of straw fine particles, apparent density of $0.75 \mathrm{~g} / \mathrm{cm}^{3}$, single-layered and using $12 \%$ of resin solids content.

- It is verified that new technologies that recommend the reuse of agricultural residues for the construction of reconstituted panels may be an option in the market in the future, presenting technical feasibility, replacement for the scarce wood as raw material and environmental demand, since some parts of the sugarcane straw could be utilized and not burned.

\section{REFERENCES}

AMERICAN NATIONAL STANDARDS INSTITUTE. ANSI A208.1-2016. Matformed wood particleboard: Specification. Gaithersburg: National Particleboard Association, 9 p., 2016.

AMERICAN SOCIETY FOR TESTING AND MATERIALS. ASTM E1755-01 (2015). Standard test method for ash in biomass. ASTM International, West Conshohocken, PA, 3 p., 2015.

ANDERSON, A.; YUNG, A.; TANAKA, T. Eco-friendly alternatives to wood-based particleboard. Available at: <http://www.stolaf.edu/people/jackson/08-124/gbreport/bioboardj05.pdf> Accessed: 25 feb. 2008.

ASSOCIAÇÃO BRASILEIRA DE NORMAS TÉCNICAS. NBR14810-1:2013. Medium density particleboards. Part 2: Requirements and test methods. Rio de Janeiro, 5 p., il, 2013.

ASSOCIAÇÃO BRASILEIRA DE NORMAS TÉCNICAS. NBR14810-2:2018. Medium density particleboards. Part 2: Requirements and test methods. Rio de Janeiro, 71 p., il, 2018.

BEKHTA, P.; KORKUT, S.; HIZIROGLU, S. Effect of pretreatment of raw material on properties of particleboard panels made from wheat straw. Bioresources, v. 8, n. 3, 4766-4774, 2013.

BRITO E. O.; PEIXOTO, G. L. Avaliação da granulometria de partículas de Pinus taeda combinadas com adesivos comerciais para a fabricação de aglomerados. Floresta e Ambiente, Rio de Janeiro, v. 7, n. 1, p. 60-67, 2000.

CARVAlHO, J. L. N.; NOGUEIROL, R. C.; MENANDRO, L. M. S.; BORDONAL, R.; BORGES, C. D.; CANTARELLA, H.; FRANCO, H. C. J. Agronomic and environmental implications of sugarcane straw removal: a major review. GCB Bioenergy. doi:10.1111/gcbb.12410, 2016.

CHANDEL, A. K.; SILVA, S. S. da; CARVALHO, W.; SINGH, O. M. V. Sugarcane bagasse and leaves: foreseeable biomass of biofuel and bio-products. J. Chem. Technol. Biotechnol, 11p., 2011.

CONAB-COMPANHIA NACIONAL DE ABASTECIMENTO. Acompanhamento da safra brasileira de canade-açúcar. Safra 2018/19 - v.5, nº 4, p. 1-75. Quarto levantamento, Brasília, abril, 2019.

DETTMER, J.; SMITH, G. D. Comparing properties of North American manufactured particleboard and medium density fiberboard - Part I: Particleboard. BioResources, v. 10, n. 3, p. 6014-6031, 2015. 
IBÁ-INDÚSTRIA BRASILEIRA de ÁRVORES. Cenários IBÁ: estatísticas da Indústria Brasileira de Árvores-no. 56 - Fevereiro de 2019. Available at: <https://www.iba.org/datafiles/e-mail-marketing/cenarios/56cenarios_2.pdf > Accessed: 05 aug. 2019.

IWAKIRI, S. Painéis de madeira reconstituída. Curitiba: FUPEF, 247 p., il. 2005.

IWAKIRI, S.; TRIANOSKI, R.; ROSA, T. S. da; COSTA, L. de S. S. da. Effects of temperature and pressure time in the manufacture of particleboards. Floresta, v. 49, n. 3, p. 383-390, 2019.

MENANDRO, L. M. S.; CANTARELlA, H.; FRANCO, H. C. J.; KÖLLN, O. T.; PIMENTA, M. T. B.; SANCHES, G. M.; RABELO, S. C.; CARVALHO, J. L. N. Comprehensive assessment of sugarcane straw: implications for biomass and bioenergy production. Society of Chemical Industry and John Wiley \& Sons, Ltd. $17 \mathrm{p}, 2017$.

SORM Inc. Particleboard with agri residues. Available at: <http://www.sorm.com/pdfs/Environmentalbenefits. pdf> Accessed: 01 aug. 2019a.

SORM Inc. Primeboard commercial blend - specifications. Available at: <http://www.sorm.com/pdfs/ commercialblend.pdf> Accessed: 01 aug. 2019b.

SORM Inc. Primeboard prairieburl - specifications. Available at: <http://www.sorm.com/pdfs/prairieburl\%20. pdf> Accessed: > Accessed: 01 aug. 2019c.

SORM Inc. Primeboard HPL panels-features. Available at: 〈http://www.sorm.com/pdfs/PrimeCoreHPL.pdf〉 Accessed: 01 aug. 2019d.

SANTANA, M. A. E.; TEIXEIRA, D. E. Use of sugarcane bagasse in the manufacture of particleboard. Brasília: Coleção Meio Ambiente, v.1, p. 1-40. 1996.

WANHUA ECOBOARD CO., LTD. Eco panels for healthy living. Available at: <http://www.wanhuaboard. com/Home/Index/plain_ecoboard.html> Accessed: 01 aug. 2019.

ZHANG, Y.; GU, J.; TAN, H.; DI, M.; ZHU, L.; XIANGLI, W. Straw based particleboard bonded with composite adhesives. Bioresources, v. 6, n. 1, p. 464-476, 2011.

ZHU, X. D.; WANG, F. H.; LIU, Y. Properties of wheat-straw boards with FRW based on interface treatment Physics Procedia, v. 32, p. 430-443, 2012. 